\title{
FEATURES OF PARAPNEUMONIC EFFUSIONS
}

\author{
Sanja Petrusevska Marinkovic, Irena Kondova Topuzovska, \\ Milena Stevanovic, Ankica Anastasovska
}

University Infectious Diseases Clinic, Medical Faculty, Skopje, Republic of Macedonia

Corresponding author: Petrusevska Marinkovic S, University Infectious Diseases Clinic, Medical Faculty, Mother Theresa, 17, Skopje, R. Macedonia, 0038972206 661, e-mail: sanjapm@yahoo.com

\section{ABSTRACT}

Introduction: Parapneumonic effusions, as a complication of community-acquired pneumonia (CAP), usually have a good course, but they sometimes progress into complicated parapneumonic effusion (CPPE) and empyema, thus becoming a significant clinical problem.

Aim: To review clinical and radiological features, as well as diagnostic and therapeutic options in parapneumonic effusions.

Material and methods: The analysis included 94 patients with parapneumonic effusion hospitalized at the University Infectious Diseases Clinic in Skopje during a 4 year period. Out of 755 patients with CAP, 175 (23.18\%), had parapneumonic effusion. Thoracentesis was performed in $94(53.71 \%)$ patients, 50 patients were with uncomplicated parapneumonic effusions (UCPPE) and 44 with complicated parapneumonic effusions (CPPE).

Results: More patients (59.57\%) were male; the average age was $53.82 \pm 17.5$ years. The most common symptoms included: fever $(91 ; 96.81 \%)$, cough $(80 ; 85.11 \%)$, pleuritic chest pain $(68 ; 72.34 \%)$, dyspnea $(65 ; 69.15 \%)$. Alcoholism was the most common comorbidity registered in $12(12.77 \%)$ patients. Macroscopically, effusion was yellow and clear in most cases $(36 ; 38.29 \%)$. Localization of pleural effusion was often in the left costophrenic angle $(53 ; 56.38 \%)$ and ultrasonographic non-septated complex. Between the two groups of effusions there was a significant difference between the ERS, WBC and CRP in serum and CRP in pleural fluid. Statistical difference existed in terms of days of hospitalization with a longer hospital stay for patients with CPPE $(\mathrm{p}<0.0001)$.

Conclusion: Patients with parapneumonic effusion have the symptoms of acute respiratory infection and frequent accompanying diseases. Future diagnostic and therapeutic treatment depends on pleural fluid features and imaging lung findings.

Keywords: parapneumonic effusion, empyema, features

\section{INTRODUCTION}

Parapneumonic effusions occur in 20 to $40 \%$ of patients who are hospitalized with pneumonia as the most common complication. [1] The mortality rate in patients with parapneu- monic effusion is higher than that in patients with pneumonia without parapneumonic effusion. [1] In one study, the morality risk was 6.5 times higher if the effusions were bilateral, 
whereas the mortality risk was 3.7 times higher if the effusions were unilateral. [2] Some of the excess mortality is a result of the mismanagement of the parapneumonic effusion. [1,3] The evolution of a parapneumonic effusion can be divided into three stages that represent a continuous spectrum. [3, 4] There is an uncomplicated parapneumonic effusion (UPPE), which is sterile exudative pleural effusion, resolved following treatment with antibiotic alone. [1, 5] The minority become secondarily infected (complicated parapneumonic effusion) (CPPE), and sometimes require drainage for resolution. [5] CPPE occurs in $10 \%$ of all patients hospitalized with effusion. [6]

Ongoing infection eventually leads to the accumulation of pus in the pleural space (empyema). Epidemiological studies describe an increasing incidence of this problem. [11] Empyema requires pleural drainage and may also require surgical treatment. [6-8] About $60 \%$ of empyemas are related to a primary pneumonic process, therefore risk factors for pleural infection are similar to those for pneumonia. [1, 9] Independent risk factors for the development of empyema include diabetes mellitus, alcohol and intravenous abuse, immunosuppression, gastroesophageal reflux disease, aspiration and poor oral hygiene. [5, $6,10]$ After a variable time interval, the pleural infection enters an organizing, stage characterized by fibroblast proliferation and the development of solid fibrous peel. This inhibits lung re-expansion and usually necessitates surgical thoracotomy and decortication. $[5,10]$

The clinical picture of parapneumonic effusions, along with symptoms of the underlying disease, pneumonia, presents symptoms typical of pleural effusion. [12] Signs and symptoms of an effusion vary depending on the underlying disease, but dyspnea, cough and pleuritic chest pain are the most common. [13] The purpose of the diagnostic protocol is to determine characteristic pneumonia and pleural effusions because the characteristics of the pleural fluid were the most reliable diagnostic parameter for assessing the type of pleural effusion which determines the further treatment of the patient. [12] Diagnosis includes radiographic examination (standard radiography, computer tomography - CT ), ultrasound, determination of markers of inflammation, basic biochemical analysis, blood culture, bacteriological and cytological examinations of sputum, pleural thoracentesis (macroscopic, biochemical, cytological and bacteriological examinations) and when there are complications, video-assisted thoracoscopy (VATS) with biopsy, and bronchoscopy. [11, 12, 13]

In 1998, Light set the foundations of the way of the treating parapneumonic effusion and empyema creating the classification of parapneumonic effusions with a treatment schema. [15]

There is considerable variation in the course and aggressiveness of parapneumonic effusions; therefore an understanding of its progression is important. [6] Increased mortality, complicated parapneumonic effusion and empyema often necessitate prolonged treatment, longer hospital stay and interventions. Thus, the identification of these patients and prompt management is important.

\section{MATERIAL AND METHODS}

Out of 755 patients, 175 (23.18\%), had parapneumonic effusion. Thoracentesis was performed in $94(53.71 \%)$ patients, 50 patients were with uncomplicated parapneumonic effusions (UCPPE) and 44 with complicated parapneumonic effusions (CPPE). The patients were diagnosed and treated in the University Infectious Diseases Clinic, Faculty of Medicine, Skopje in the Department of Respiratory Diseases in the period from September 2011 to June 2015. Individuals were excluded from the study because of cancer and malignant effusion, transudative effusion, vacuities, pulmonary emboli (PE), tuberculosis and age less than 18 years.

The demographic characteristics, physical examination findings, laboratory and microbiological findings of all study participants were monitored regularly at the University Infectious Diseases Clinic. Initial lung X-rays were taken for all patients at the Institute of Radiology, Medical Faculty in Skopje. After admission, all the patients underwent an ultrasound of the pleura and the lung with a three- dimensional echo at the University Infectious Diseases Clinic for diagnosis of pleural effusions and also diagnostic thoracocentesis if the size of effusion was larger than $10 \mathrm{~mm}$. After verification of pneumonia and pleural effusion, the distinction between transudation and exudates was done according to Light's criteria. Exudative pleural effusion is one that meets at least one of the criteria of Light. 
The transudative is the effusion that meets all three criteria at the same time: 1) to have intercourse protein $\mathrm{p} / \mathrm{s}$ below $0.5 ; 2$ ) intercourse lactate dehydrogenase (LDH) p/s below 0.6 , and 3 ) $\mathrm{LDH}$ in pleural fluid under $282 \mathrm{U} / \mathrm{L}$, which is the lowest limit in our laboratory.

Then, the exudative pleural effusions according to their evolution and on the basis of $\mathrm{pH}$, glucose and LDH value in the pleural fluid are divided into: - Uncomplicated parapneumonic effusions: $\mathrm{pH}>7.2$, glucose $>60 \mathrm{mg} / \mathrm{dl}, \mathrm{LDH}$ $<1000 \mathrm{UI} / \mathrm{ml}$; - Complicated parapneumonic effusions: $\mathrm{pH}<7.2$, glucose $<60 \mathrm{mg} / \mathrm{dl}, \mathrm{LDH}>/=$ $1000 \mathrm{UI} / \mathrm{ml}$.

Pleural fluid obtained by thoracentesis was sent for a series of biochemical, cytological, histopathological and microbiological tests in order to determine the nature of the effusion. The following tests of the pleural fluid were performed:

Physical - Colour, turbidity, viscosity.

Biochemical- Glucose, Protein, Albumin, Lactate dehydrogenase (LDH), $\mathrm{pH}$ - in the biochemical laboratory of the Infectious Diseases Clinic.

Cytological examination of the pleural fluid- at the Institute of Oncology.

Microbiological examination of the pleural fluid- at the Institute for Microbiology and Parasitology.

Special tests- ADA (adenosine deaminase), lyzozyme and culture for ARB (acid-resistant bacilli) and culture for Lewenstain- at the Institute for lung diseases and tuberculosis.

ERS was determined in all three groups of patients at admission in the Clinic. ERS measures the distance through which erythrocytes fall within 1hour in a vertical tube of anticoagulated blood, and is measured in millimetres/hour. The blood is drawn into a vertical tube anticoagulated with sodium citrate. Leukocyte count (WBC) in serum was also determined in the biochemical laboratory of the Infectious Diseases Clinic, by the white blood cell counter (number per microliter). The amount of protein in serum was determined in the same biochemical laboratory with a standard method. C-reactive protein (CRP) in serum and pleural fluid was measured by quantitative methods in the biochemistry laboratory of same clinic with quantitative sandwich enzyme heterogeneous test, the Ektahem Clinical Chemistry test, with an automated biochemical analyser Vitros 250.

\section{Statistical analysis}

Statistical analysis was conducted using SPSS 17 for Windows. For the testing of normality in the distribution of the data we used the Kolmogorov-Smirnov and Shapiro-Wilk's $\mathrm{W}$ tests. Categorical traits were displayed by absolute and relative representation with quantitative traits mean, SD, median, minimum, maximum, 25-75 percentiles. To compare the three groups of subjects in relation to the variables analyzed we used Kruskal-Wallis ANOVA and Mann-Whitney U test (Z). For the level of significance or importance, we took the value of $p$ $<0.05$, a significant higher value of $p<0.01$.

\section{RESULTS}

Demographic characteristic of respondents

Out of 755 patients with CAP, 175 (23.18\%), had parapneumonic effusion The patients were diagnosed and treated in the University Infectious Diseases Clinic, Faculty of Medicine, Skopje in the Department of Respiratory Diseases in the period from September 2011 to June 2015. Thoracentesis was performed in 94 $(53.71 \%)$ patients, 50 patients were with uncomplicated parapneumonic effusions (UCPPE) and 44 with complicated parapneumonic effusions (CPPE).

Gender structure of patients with parapneumonic effusion comprised $59.57 \%$ male and $40.43 \%$ female respondents, and their average age was $53.82 \pm 17.5$ years. The oldest participant was 93 years, and the youngest 18 years. Of all patients, $72.34 \%$ were smokers. Exactly $37(39.36 \%)$ of the participants had previous pneumonia and antibiotic before hospitalization received 61 (64.89\%) patients Positive epidemiological survey had $34 \%$ of respondents. The results are shown in Table 1.

Regarding the seasonal distribution of parapneumonic effusions in this group of patients, the majority of cases were in January $(17.2 \%)$, then in March and December (11.7\%) of hospitalized patients with parapneumonic effusion.

\section{Accompanying diseases}

Accompanying chronic diseases had $65.96 \%$ of the participants. The most common comorbid condition, alcoholism, was registered 
in $12.77 \%$ of patients with parapneumonic effusion, then diabetes mellitus in $10.64 \%$ of patients, and chronic heart diseases in $9(9.57 \%)$. A significant number of patients $8(8.51 \%)$ had two or three comorbidities.

Table 1. Demographic characteristics of the patients with parapneumonic effusion

\begin{tabular}{|c|c|}
\hline \multicolumn{2}{|l|}{ Age } \\
\hline \multicolumn{2}{|c|}{$\operatorname{mean} \pm \mathrm{SD}(53.82 \pm 17.5) \quad \min -\max (18-93)$} \\
\hline \multicolumn{2}{|l|}{$\operatorname{Sex} n(\%)$} \\
\hline male & $56(59.57)$ \\
\hline female & $38(40.43)$ \\
\hline \multicolumn{2}{|l|}{ Comorbidity n (\%) } \\
\hline Yes & $62(65.96)$ \\
\hline No & $32(34.04)$ \\
\hline \multicolumn{2}{|l|}{ Type of comorbidity n (\%) } \\
\hline chronic lung disease & $4(4.25)$ \\
\hline chronic heart disease & $9(9.57)$ \\
\hline diabetes mellitus & $10(10.64)$ \\
\hline chronic liver disease & $2(2.13)$ \\
\hline chronic renal failure & $1(1,06)$ \\
\hline Alcoholism & $12(12.77)$ \\
\hline Malignancy & $6(6.38)$ \\
\hline chronic systemic disease & $3(3.19)$ \\
\hline poor dental hygiene & $2(2.13)$ \\
\hline drug addiction & $2(2.13)$ \\
\hline neurological disease & $2(2.13)$ \\
\hline two or three comorbidities & $8(8.51)$ \\
\hline other diseases & $1(1.06)$ \\
\hline Smokers n (\%) & $68(72.34)$ \\
\hline Contact with similar patients n (\%) & $32(34.04)$ \\
\hline Previous pneumonia n (\%) & $37(39.36)$ \\
\hline Antibiotics before hospitalization & $61(64.89 \%)$ \\
\hline
\end{tabular}

\section{Presence of symptoms}

The most common general symptoms in patients with parapneumonic effusion were fever in $91(96.81 \%)$ and fatigue in 89 (94.68\%). Out of symptoms that are more specific for parapneumonic effusions patients usually had pleuritic chest pain $68(72.34 \%)$ and dyspnea $(65$; $69.15 \%$ ). Weight loss was also an often represented symptom in $68(72.34 \%)$ cases.

Cough was present in 80 (85.1\%) patients, most frequently productive with expectoration of purulent sputum in $32(34.04 \%)$ patients. Haemoptysis had $8(8.51 \%)$ patients.

The average value of temperature before hospitalization was $39.11 \pm 1.00 \mathrm{C}$, with average duration of temperature (5.62 \pm 5.2$)$ days, with the shortest duration of 1 day and a maximum of 35 days. During hospitalization, the average value of temperature was lower $38.69 \pm 1.10 \mathrm{C}$, with patients who did not have a temperature, and with the longest duration of 24 days.
Dullness to percussion had $62(65.96 \%)$ patients, with depress type of breathing in 52 $(55.32 \%)$ of cases. The shortest duration of auscultatory findings was 7 days, the longest 29 days, the average length of findings of auscultation was $15.87 \pm 4.7$ days. In $50 \%$ of respondents with parapneumonic effusion, auscultatory findings persisted for more than 15 days. With impaired breathing were $52(55.32 \%)$ patients and without $22(23.4 \%)$ patients. Tachypnea or more than 30 breaths per minute was found in $46.81 \%$ of the respondents.

$11.7 \%$ of the respondents had registered a change in mental status or alteration of consciousness in terms of somnolence. Those patients were admitted in the intensive care unit until stabilization and normalization of the vital parameters. (Table 2)

\section{Radiographic finding}

Alveolar infiltrates were present in $51(54.25 \%)$ participants, while mixed (alveointerstitial infiltrate) in $41(41.49 \%)$ of them. When it comes to distribution according to extensiveness, diffuse infiltrates were verified in $37(39.36 \%)$ cases, and then segmental in 35 $(37.23 \%)$, and lobar in $19(20.21 \%)$ of all cases. Sparsely changes in lung were multilocular in only $19.3 \%$ of respondents with parapneumonic effusion. Most respondents had unilaterally distribution of changes in the lung, 67 (71.28\%), while bilateral infiltrate were observed in 27 $(28.72 \%)$ respondents.

Table 2. Clinical and radiographic features of patients with parapneumonic effusion

\begin{tabular}{|ll|}
\hline SYMPTOMS & N (\%) \\
\hline Presence of catarrhal symptoms & $27(28.72)$ \\
\hline sore throat & $25(26.6)$ \\
\hline hyperemia of tonsilofarings & $40(42.55)$ \\
\hline Type of cough & \\
\hline productive purulent & $32(34.04)$ \\
productive with mucous sputum & $18(19.15)$ \\
haemoptysis & $8(8.51)$ \\
dry cough & $22(23.4)$ \\
no cough & $14(14.89)$ \\
\hline mental change (somnolence) & $11(11.70)$ \\
\hline headache & $56(59.57)$ \\
\hline Fatigue & $89(94.68)$ \\
\hline myalgia & $47(50)$ \\
\hline arthralgia & $36(38.3)$ \\
\hline weight loss & $68(72.34)$ \\
\hline
\end{tabular}




\begin{tabular}{|l|l|}
\hline Dyspnea & $65(69.15)$ \\
\hline pleuritic chest pain & $68(72.34)$ \\
\hline herpes labialis & $18(19.15)$ \\
\hline vomiting & $25(26.6)$ \\
\hline diarrhoea & $14(14.89)$ \\
\hline fever & $91(96,81)$ \\
\hline Number of respirations & $\operatorname{mean} \pm \mathrm{SD}(28.12 \pm 4.9)$ \\
& $\begin{array}{l}\min -\max (18-38) \\
\operatorname{median}(\mathrm{IQR})=4(\text { range }\end{array}$ \\
& $18-38)$ \\
\hline respirations $\geq 30 \mathrm{~min}$. & $44(46.81)$ \\
\hline
\end{tabular}

Values of temperature before hospitalization ${ }^{\circ} \mathrm{C}$

mean $\pm \mathrm{SD}(39.11 \pm 1.0) \min -\max (37.2-41.0)$ median $=39$ (range $38.5-40)$

Duration of temperature before hospitalization (days)

mean $\pm \mathrm{SD}(5.62 \pm 5.2) \quad \min -\max (1-35) \quad$ median $=4($ range $3-7)$

Values of temperature during hospitalization, ${ }^{\circ} \mathrm{C}$

mean \pm SD $(38.69 \pm 1.1) \quad \min -\max (36-41)$ median $=38.7$ (range $37.8-39.7)$

Duration of temperature during hospitalization (days)

mean $\pm \mathrm{SD}(3.99 \pm 3.8) \min -\max (0-24)$ median $=3($ range $2-5)$

\begin{tabular}{|c|c|}
\hline Auscultatory findings & $\mathbf{N}(\%)$ \\
\hline \multicolumn{2}{|l|}{ Dullness to percussion } \\
\hline Yes & $62(65.96)$ \\
\hline Not & $32(34.04)$ \\
\hline \multicolumn{2}{|l|}{ auscultation (type of breathing) } \\
\hline vesicular & $15(15.96)$ \\
\hline aggravated & $4(4.25)$ \\
\hline bronchial & $1(1.06)$ \\
\hline impaired (depress) & $52(55.32)$ \\
\hline Silent & $22(23.4)$ \\
\hline \multicolumn{2}{|l|}{ duration of auscultatory findings (day) } \\
\hline $\begin{array}{l}\operatorname{mean} \pm \operatorname{SD}(15.87 \pm 4.7) \\
(\text { range } 12-19)\end{array}$ & median $(\mathrm{IQR})=15$ \\
\hline Radiographic finding & $\mathbf{N}(\%)$ \\
\hline \multicolumn{2}{|l|}{ Ro type of infiltration } \\
\hline alveolar infiltrates & $51(54.25)$ \\
\hline interstitial infiltrate & $4(4.25)$ \\
\hline mixed (alveo- interstitial infiltrate) & $41(41.49)$ \\
\hline \multicolumn{2}{|l|}{ Distribution according extensiveness } \\
\hline diffuse & $37(39.36)$ \\
\hline multilocular & $3(3.19)$ \\
\hline Lobar & $19(20.21)$ \\
\hline segmental & $35(37.23)$ \\
\hline \multicolumn{2}{|l|}{ Distribution of changes in lung } \\
\hline unilaterally & $67(71.28)$ \\
\hline bilaterally & $27(28.72)$ \\
\hline interstitial & $2(2.13)$ \\
\hline
\end{tabular}

\section{Microbiological findings}

Positive cultures of pleural punctate by a microbiological examination of the pleural fluid of the majority of patients were present in $14(14.89 \%)$ patients, $4(4.25 \%)$ of them were with Peptostreptococcus, than Staphylococcus aureus and MRSA in $3(3.19 \%)$ patients. Streptococcus pneumoniae was isolated in $2(2.13 \%)$ patients. All pleural fluid with direct examination of the bacilli under a microscope, with BACTEC method and Lewenstain culture were negative.

Table 3. Characteristics of pleural fluid in patients with parapneumonic effusions

\begin{tabular}{|c|c|}
\hline variable & $\mathbf{N}(\%)$ \\
\hline \multicolumn{2}{|l|}{ Culture of pleural fluid } \\
\hline Staphylococcus aureus & $3(3.19)$ \\
\hline MRSA (methicillin resistant staphylococcus) & $3(3.19)$ \\
\hline Streptococcus pneumoniae & $2(2.13)$ \\
\hline Streptococcus pyogenes & $1(1.06)$ \\
\hline Anaerobes (Peptostreptococcus) & $4(4.25)$ \\
\hline Echerichia coli & $1(1.06)$ \\
\hline negative & $80(85.11)$ \\
\hline \multicolumn{2}{|l|}{ Localization of pleural effusion } \\
\hline Right & $31(32.98)$ \\
\hline Left & $53(56.38)$ \\
\hline bilateral & $4(4.25)$ \\
\hline right between between the lobes & $4(4.25)$ \\
\hline left between the lobes & $2(2.13)$ \\
\hline \multicolumn{2}{|l|}{ Height of pleural effusion in $\mathbf{m m}$} \\
\hline $\begin{array}{l}\operatorname{mean} \pm \mathrm{SD}(34.74 \pm 26.9) \quad \min -\max (1-140) \\
\text { (range } 18-42)\end{array}$ & median $(\mathrm{IQR})=25$ \\
\hline \multicolumn{2}{|c|}{ Drainage at the Clinic for Thoraco-cardiovascular Surgery } \\
\hline Yes & $8.51)$ \\
\hline Not & $(91.49)$ \\
\hline \multicolumn{2}{|l|}{ Therapeutic thoracentesis } \\
\hline Yes & $10(10.64)$ \\
\hline No & $84(89.36)$ \\
\hline \multicolumn{2}{|l|}{ Macroscopic appearance of pleural effusion } \\
\hline clear yellow & $36(38.29)$ \\
\hline Yellow cloudy & $34(36.17)$ \\
\hline orange & $5(5.32)$ \\
\hline haemorrhagic & $9(9.57)$ \\
\hline brown & $5(5.32)$ \\
\hline Greenish & $5(5.32)$ \\
\hline \multicolumn{2}{|l|}{ Sonographic appearance of pleural effusion } \\
\hline Complex non-septated & $48(51.06)$ \\
\hline Complex septated & $28(29.78)$ \\
\hline Homogeneously echogenic & $18(19.15)$ \\
\hline
\end{tabular}


Markers of inflammation in patients with UCPPE and CPPE

There was a statistically significant difference between the values of the ERS in both groups of patients, with higher values in patients with CPPE. Average value of ERS in these patients was $74.77 \pm 27.3 \mathrm{~mm} / \mathrm{h}$. Patients with CPPE had significant higher average values of CRP in serum at admission, $231.79 \pm 112.2 \mathrm{mg} / 1$, in relation to patients with UCPPE, $163.8 \pm 147.9 \mathrm{mg} / \mathrm{l}$. The two groups were statistically different by the values of white blood cells (WBC) $(p=0.013)$. Higher values of WBC had patients with CPPE, with average value of $14.68 \pm 6.6 \times 109$, unlike patients with UCPPE with an average of $12.19 \pm$ $6.0 \times 10^{9}$

Table 4. Markers of inflammation in patients with UCPPE and CPPE

\begin{tabular}{|c|c|c|c|}
\hline \multicolumn{4}{|c|}{$\begin{array}{l}\text { Markers of inflammation in two groups patients with the } \\
\text { parapneumonic effusions }\end{array}$} \\
\hline Variable & $\begin{array}{l}\text { UCPPE } \\
\mathbf{N}=50\end{array}$ & $\begin{array}{l}\text { CPPE } \\
\mathrm{N}=44\end{array}$ & $\mathrm{p}$ value \\
\hline \multicolumn{4}{|c|}{ ERS mm/h - admission $n(\%)$} \\
\hline$\leq 20$ & $4(8)$ & $2(4.55)$ & \multirow{5}{*}{${ }^{\mathrm{b}} \mathrm{p}=0.14$} \\
\hline $21-40$ & $8(16)$ & $6(13.64)$ & \\
\hline $41-60$ & $19(38)$ & $8(18.18)$ & \\
\hline $61-100$ & $17(34)$ & $24(54.55)$ & \\
\hline$>100$ & $2(4)$ & $4(9.09)$ & \\
\hline \multicolumn{4}{|c|}{ ERS $\mathrm{mm} / \mathrm{h} \quad$ mean $\pm \mathrm{SD} \quad$ median $\left(25-75^{\text {th }}\right.$ quartiles $)$} \\
\hline \multirow[t]{2}{*}{ admission } & $60.02 \pm 27.7$ & $74.77 \pm 27.3$ & \multirow[b]{2}{*}{${ }^{c} \mathrm{p}=0.03 *$} \\
\hline & $55(45-80)$ & $76.5(60-97)$ & \\
\hline \multirow[t]{2}{*}{ discharge } & $36.12 \pm 22.2$ & $41.73 \pm 26.8$ & \multirow[t]{2}{*}{${ }^{\mathrm{b}} \mathrm{p}=0.3$} \\
\hline & $40(15-52)$ & $40(20-60)$ & \\
\hline \multicolumn{4}{|c|}{ WBC $\times 10^{9} / \mathrm{L}$ mean $\pm \mathrm{SD}$ median $\left(25-75^{\text {th }}\right.$ quartiles $)$} \\
\hline \multirow[t]{2}{*}{ admission } & $12.19 \pm 6.0$ & $14.68 \pm 6.6$ & \multirow[t]{2}{*}{$\mathrm{c} p=0.013^{*}$} \\
\hline & $11.1(8.1-16.7)$ & $12.6(10.2-20.2)$ & \\
\hline \multirow[t]{2}{*}{ discharge } & $7.26 \pm 1.9$ & $7.62 \pm 2.8$ & \multirow[t]{2}{*}{${ }^{\mathrm{b}} \mathrm{p}=0.26$} \\
\hline & $7.5(5.8-8.6)$ & $6.8(6-8.8)$ & \\
\hline CRP serum & $\mathrm{mg} / \mathrm{l} \quad$ mean $\pm \mathrm{SD}$ & median $\left(25-75^{\text {th }}\right.$ qua & iles) \\
\hline \multirow[t]{2}{*}{ admission } & $163.8 \pm 147.9$ & $231.79 \pm 112.2$ & \multirow[b]{2}{*}{${ }^{\mathrm{b}} \mathrm{p}=0.00028^{* *}$} \\
\hline & $120.5(63-204)$ & $12.6(10.2-20.2)$ & \\
\hline \multirow[t]{2}{*}{ discharge } & $12.6 \pm 16.1$ & $32.43 \pm 47.3$ & \multirow[b]{2}{*}{${ }^{\mathrm{b}} \mathrm{p}=0.04^{*}$} \\
\hline & $7(3-14)$ & $17(4.5-33.5)$ & \\
\hline
\end{tabular}

${ }^{\mathrm{b}} \mathrm{p}$ (Mann-Whitney test) ${ }^{\mathrm{c}}$ (Student-ov $\mathrm{t}$ test) ${ }^{*} \mathrm{p}<0.05$ $* * \mathrm{p}<0.01$

Biochemical characteristics of pleural fluid in patients with parapneumonic effusion

Values of LDH, $\mathrm{pH}$ and glucose are important to separate the uncomplicated and complicated parapneumonic effusions and monitor the stage of the disease. The statistical differ- ence with higher values of LDH in CPPE and lower values of $\mathrm{pH}$ and glucose in CPPE, unlike UCPPE was expected.

Besides the three classic parameters used for separation of parapneumonic effusions, $\mathrm{LDH}$, glucose and $\mathrm{pH}$, in all patients CRP was also measured in the pleural fluid. Higher values of CRP in pleural punctate had patients with CPPE $(p<0.001)$, with average value of $150.8 \pm$ $65.9 \mathrm{mg} / 1$, unlike UCPPE with average value of $58.1 \pm 42.3 \mathrm{mg} / \mathrm{l}$.

Table 5. Biochemical characteristics of pleural fluid in patients with parapneumonic effusion

\begin{tabular}{|c|c|c|c|}
\hline variable & $\begin{array}{l}\text { UCPPE } \\
\mathrm{N}=50\end{array}$ & $\begin{array}{l}\mathrm{CPPE} \\
\mathrm{N}=44\end{array}$ & $\mathrm{p}$ value \\
\hline \multirow[t]{3}{*}{ LDH } & mean $\pm \mathrm{SD}$ & median $\left(25-75^{\text {th }}\right.$ quartiles $)$ & \\
\hline & $556.18 \pm 179.4$ & $1689.3 \pm 1202.7$ & ${ }^{\mathrm{a}} \mathrm{p}<0.001 *$ \\
\hline & $491.5(435-669)$ & $1462(1090.5-1810.5)$ & \\
\hline \multirow[t]{3}{*}{$\mathrm{pH}$} & mean $\pm \mathrm{SD}$ & $\min -\max$ & \\
\hline & $7.42 \pm 0.05$ & $7.19 \pm 0.1$ & ${ }^{\mathrm{b}} \mathrm{p}<0.001 * *$ \\
\hline & $7.23-7.53$ & $6.8-7.38$ & \\
\hline \multicolumn{4}{|c|}{ Glucose $\mathrm{mmol} / 1$ mean $\pm \mathrm{SD}$} \\
\hline & $5.27 \pm 1.4$ & $2.98 \pm 0.7$ & ${ }^{\mathrm{b}} \mathrm{p}<0.001 * *$ \\
\hline & $3.4-12.3$ & $1-4.8$ & \\
\hline \multirow[t]{3}{*}{ CRP } & $\mathrm{ng} / \mathrm{l} \quad$ mean $\pm \mathrm{SD}$ & median ( $25-75^{\text {th }}$ quartiles $)$ & \\
\hline & $58.1 \pm 42.3$ & $150.8 \pm 65.9$ & ${ }^{\mathrm{a}} \mathrm{p}<0.001^{*}$ \\
\hline & $59.5(25-75)$ & $146.5(114.5-183)$ & \\
\hline
\end{tabular}

${ }^{\mathrm{a}} \mathrm{p}$ ( Mann-Whitney test) ${ }^{\mathrm{b}} \mathrm{p}$ (Student-ov test) ${ }^{*} \mathrm{p}<0.05$ $* * \mathrm{p}<0.01$

Antibiotic treatment of patients with parapneumonic effusions

According to the recommendations for the treatment of patients with CAP and parapneumonic effusions most patients with complicated parapneumonic effusion were treated with cephalosporin 3rd gen. and clindamycin. In patients who had no good response, we used cephalosporin in combination with vankomycin and metronidazole. A majority of patients with uncomplicated parapneumonic effusion were treated with cephalosporin $3^{\text {rd }}$ gen combined with a quinolone or macrolide or tetracycline.

\section{Length of hospitalization}

There was statistically significant difference in the hospital days between the two groups. Length of hospitalization and hospital treatment in respondents with CPPE lasted $20.75 \pm 18$ days and in those with UCPPE $15.78 \pm 4.3$ days. 
Table 5. Antibiotic treatment of patients with parapneumonic effusions and length of hospitalization

\begin{tabular}{|c|c|c|}
\hline \multicolumn{2}{|l|}{ variable } & $\mathbf{N}(\%)$ \\
\hline \multicolumn{3}{|c|}{ Antibiotic treatment after hospitalization } \\
\hline \multicolumn{2}{|c|}{$\begin{array}{l}\text { Cephalosp, 3rd Gen+ quinolones or macrolide or } \\
\text { tetracycline } \\
\text { Cephalosporins, 3rd gen }+ \text { clindamycin }\end{array}$} & $\begin{array}{l}18(19.15) \\
28 \\
(29.79)\end{array}$ \\
\hline \multicolumn{2}{|c|}{ Cephalosporins, 3rd gen + Vankomycin + Metronidazole } & $26(27.66)$ \\
\hline \multicolumn{2}{|l|}{ Cephalosporins, 3rd gen+ Vankomycin } & $\begin{array}{l}10 \\
(10.63)\end{array}$ \\
\hline \multicolumn{2}{|l|}{ Imipenem+Vankomicin } & $7 \cdot(7.4)$ \\
\hline \multicolumn{2}{|l|}{ Cephalosporins, 3rd gen } & $2(2.13)$ \\
\hline \multirow{2}{*}{\multicolumn{2}{|c|}{$\begin{array}{l}\text { Cephalosporins, 3rd gen }+ \text { aminoglycosides } \\
\text { other therapy }\end{array}$}} & $1(1.06)$ \\
\hline & & $2(2.13)$ \\
\hline \multirow{3}{*}{$\begin{array}{l}\text { Length of hospitalizatic } \\
\text { (25-75 quartiles) } \\
\text { Variable }\end{array}$} & edian & p value \\
\hline & $\begin{array}{c}\text { CPPE } \\
\text { N=44 }\end{array}$ & \\
\hline & $\begin{array}{c}20.75 \pm 18 \\
21(18-23)\end{array}$ & $\stackrel{{ }^{\mathrm{b}} \mathrm{p}}{<0.0001 * *}$ \\
\hline
\end{tabular}

${ }^{\mathrm{a}} \mathrm{p}$ ( Chi-square test) ${ }^{\mathrm{b}} \mathrm{p}$ (Mann-Whitney test) ${ }^{*} \mathrm{p}<0.05 * * \mathrm{p}<0.01$

\section{DISCUSSION}

Parapneumonic effusions occur in 20 to $40 \%$ of patients who are hospitalized with pneumonia. [1, 2] This information is correlated with our study where parapneumonic effusion is verified in $23.18 \%$ of patients hospitalized with CAP. In our study, $59.57 \%$ were male that correlate with Dzurik's study where out of 130 patients with parapneumonic effusion, $60 \%$ were men. [12] The result is correlated with the tests of Ozol and Tsang where greater number of participants were males who had more inclination to develop CPPE. $[17,18]$ Average age among our respondents was $53.82 \pm 17.5$ years; the oldest was 93 years old and the youngest 18 years. Age correlates with the age of patients in several studies. [12, 19, 20]

We mentioned that there are comorbidities as risk factors for the development of complicated parapneumonic effusions especially empyema. Accompanying chronic diseases had $65.96 \%$ of the participants. The most common comorbid condition, alcoholism, was registered in $12.77 \%$ of patients with parapneumonic effusion, then diabetes mellitus in $10.64 \%$ of patients, and chronic heart diseases in $9(9.57 \%)$. A significant number of patients $8(8.51 \%)$ had two or three comorbidities. A recent Falguera's study [11] analyzed 4715 patients with CAP and 882 (19\%) had pleural effusion, of which $261(30 \%)$ had complicated parapneumonic effusion or empyema. In this study with a multivariable analysis, no single baseline patient's characteristics distinguished patients without pleural effusion from those with uncom- plicated parapneumonic effusion. However, five independent baseline characteristics could predict the development of complicated parapneumonic effusion or empyema: age $<60$ years old, alcoholism, pleural pain, tachycardia and leucocytosis. In the Chalmer's study also realized in 2011, [19] as in our study, alcoholism was the most common comorbidity which was noted in patients with CPPE, than followed by diabetes mellitus. In this study, having more than one comorbidity proved significant in the development of parapneumonic effusion. In an earlier study as the most common comorbidity when it comes to CPPE was reported diabetes mellitus. [5, 8] Perhaps the explanation of alcoholism, as a significant risk factor is the existence of anaerobic infections in these patients, associated with poor dental hygiene and aspiration. Share of associated diseases and age over 60 years, are risk factors for death in patients with empyema of the pleura. [12] CPPE and empyema occur commonly however, in the absence of any identifiable risk factors. [5]

The most common general symptoms in patients with parapneumonic effusion in the study conducted were fever in $91(96.81 \%)$ and fatigue in $89(94.68 \%)$. Out of symptoms more specific for parapneumonic effusions patients usually had pleuritic chest pain 68 (72.34\%) and dyspnea (65; $69.15 \%$ ). Unfortunately, the symptoms of pneumonia involving parapneumonic effusion or empyema (i.e. fever, malaise, cough, dyspnea and pleural chest pain) are similar to those of pneumonia without a parapneumonic effusion. [1, 5] The symptoms of a parapneumonic effusion can be either acute or chronic. [1, 5, 8] Anaerobic pulmonary infections frequently have an associated pleural effusion and are characterized by a more chronic course. $[1,5,21]$ Similarly, if the patients have a parapneumonic effusion, the clinical picture is similar whether or not the effusion is complicated. [1] Weight loss and anaemia are common with anaerobic infection. [1,5] In our patients weight loss was also an often represented symptom in $68(72.34 \%)$ cases. Yet, in the said Falguera's study, chest pain is an important predictive factor for the development of complicated parapneumonic effusion. [21] Because of that, symptoms which are disease specific for pleural infection should not be overlooked. [19, 20,21]

Other common symptom is the fever. High temperature that persists in patients with pneumonia suggests that the inflammatory process takes adverse course and is complicating with the development of parapneumonic effusion. $[5,22]$ 
We found that during hospitalization, the average value of temperature was lower $38.69 \pm 1.10 \mathrm{C}$ in patients who did not have high temperature, with the longest duration of it to 24 days. The parapneumonic effusion should be suspected when in the last 48 hours of antibiotic treatment response is still weak or the patient still has fever or when it is determined that here is an increase in the number of leukocytes ( WBC ) and the value of C-reactive protein (CRP). [14]

In this study, dullness to percussion was noticed in $62(65.96 \%)$ patients, with depress type of breathing in $52(55.32 \%)$ of cases. The shortest duration of auscultatory findings was 7 days, the longest 29 days, the average length of findings of auscultation was $15.87 \pm 4.7$ days. In $50 \%$ of respondents with parapneumonic effusion, auscultatory findings persisted for more than 15 days. With impaired breathing were $52(55.32 \%)$ patient and completely silent $22(23.4 \%)$ patients. Tachypnea or more than 30 breaths per minute was observed in $46.81 \%$ of the respondents. Dullness to percussion with impaired breathing or completely silent breathing clearly indicate that the patient has pneumonia and parapneumonic effusion. [1,23]

Exactly $11.7 \%$ of the respondents had registered a change in mental status or alteration of consciousness in terms of somnolence. Tachypnea $>30$ breaths per minute and mental alteration are factors that predict severity and are included in the scores that predict mortality and patient require hospitalization in intensive care units (ICU). [19, 21, 24]

At hospital admission all patients were subjected to lung X-rays. Alveolar infiltrates were present in $51(54.25 \%)$ participants, while mixed (alveo- interstitial infiltrate) in $41(41.49 \%)$ of them. When it comes to distribution according to extensiveness, diffuse infiltrates were verified in $37(39.36 \%)$ cases, and then segmental in 35 $(37.23 \%)$, and lobar in $19(20.21 \%)$ of all cases. Bilateral infiltrate was observed in $27(28.72 \%)$ respondents. Hasley et al. associate in there study with 1906 patients with univariate regression analyses the following radiographic characteristics to be significantly associated with 30-day mortality: 1) bilateral pleural effusions; 2) a pleural effusion of moderate or greater size; 3 ) 2 or more lobes involved with infiltrate; 4) bilateral infiltrate. [2] Analysis of the chest with $\mathrm{x}$ - ray is important in everyday practice with an opportunity to indicate the severity of the disease and the possible outcome for the patient. [2, 25]
When we are discussing radiographic findings we must mention ultrasound findings of the pleura and lung. Localization of pleural effusion was often in the left costophrenic angle (53; $56.38 \%$ ), than in the right costophrenic angle, 31 $(32.98 \%)$. Bilateral pleural effusion was noted in $4(4.25 \%)$ patients. In the mentioned study of Hasley, bilateral pleural effusion has been singled out as an independent factor for prediction of mortality in patients with effusion. [2]

Complex non-septated was verified in 48 $(51.06 \%)$ participants, complex septated in 28 (29.78\%), and homogeneously echogenic in 18 (19.15\%) patients. Patients with complex septated sonographic pattern had a poorer prognosis for a successful outcome, higher ICU admission rate and a higher mortality rate. [25] The value of ultrasound of pleural effusion is well documented. [26, 27] Even small amounts of pleural effusion can be detected. Ultrasound is helpful in determining the nature of pleural opacity, identifying minimal of loculated effusion, and discriminating between subpulmonary and subphrenic effusions. It is portable and position flexible, and some studies give it an advantage over computed tomography (CT) in the management of pleural effusions. [25]

Positive cultures of pleural punctate had 14 (31.81\%) patients by a microbiological examination of the pleural fluid of the patient with CPPE. In $4(4.25 \%)$ cases, Peptostreptococcus was isolated, than Staphylococcus aureus and MRSA in $3(3.19 \%)$ patients. Streptococcus pneumoniae was isolated in $2(2.13 \%)$ patients. Global studies report higher numbers of positive pleural punctate which is $32-50 \%$ of cases. [25, 28, 29] Our finding fit in the percentage of isolates. In CPPE and empyema in which expected positive isolate culture of points usually as agents are reported gram- positive organisam Streptococcus pneumoniae, gram- negative (Haemophylus influenza), anaerobes (Bacteroid melanogenicus, Peptostreptococcus). [29] But more recent studies in outpatient parapneumonic effusions meet increasingly Staphylococcus aureus, Streptococcus milleri, MRSA, Pseudomonas aeruginosa, Klebsiella pneumoniae and Escherichia coli. [21, $25,28]$ Therefore, there are changes in antibiotic treatment in CPPE and empyema. [30]

The initial antibiotic cover of patients with parapneumonic effusion is generally dictated by treatment guidelines for pneumonia, and is altered according to blood and pleural fluid microbial 
sensitivities. [8] Empirical anaerobic antibiotic cover is generally advised. [5] Choices in community- acquired complicated parapneumonc effusion/empyema include intravenous amoxicillin with clavulanic acid or a combination of a second generation cephalosporin and metronidazole. [8, 30] Clindamycin monotherapy is an effective for patients with beta lactam allergy. [8, 30] Possible choices include carbapenems, antipseudomonal penicillins, or third or fourth generation cephalosporins with metdonidazole in patients with community- acquired empyema or nosocomial empyema. Vankomycin, linezolid or alternatives may have to be added for suspected or proven meticillin- resistant S. aureus infection. Aminoglicosides demonstrate poor pleural penetration and reduced efficacy in acidic environments and should be avoided. [8, 19, 30] In a recommendation of the Spanish society of pulmonology and thoracic surgery, cephalosporin it recommended though the penetration into the pleural cavity is slow, but concentrations are stable and persistent. [30] The penetration of quinolones is better than that of the penicillin. [30] According to these recommendations there was a summary that in all cases, empiric antibiotic treatment must be started as early as possible and subsequently adjusted in light of the results of cultures. the characteristics of the patients are significant, the microbiological peculiarities of the local geographical area, and the activity of the chosen antibiotic in pleural fluid. $[19,30]$

In this study, part of patients with uncomplicated parapneumonic effusion, 18 (19.15\%), according to the recommendations for the treatment of patients with CAP, were treated with cephalosporin 3rd gen combined with a quinolone or macrolide or tetracycline. Most patients, 28 (29.79\%) were treated with cephalosporin $3 \mathrm{rd}$ gen. and clindamycin. In patients who had no good response, we used cephalosporin in combination with vankomycin and metronidazole. Some patients were treated according to the microbiological findings.

There was a statistically significant difference between the values of the ERS, WBC and CRP in serum in both groups of patients, with higher values in patients with CPPE. ERS, WBC and CRP as a marker of inflammation strongly suggests that if some clinical symptoms persist for a longer time and there is no effect of antibiotic treatment, the effusion is complicating. [5, 22] Besides the three classic parameters used for sepa- ration of parapneumonic effusions, $\mathrm{LDH}$, glucose and $\mathrm{pH}, \mathrm{CRP}$ was also measured in the pleural fluid of all patients. Higher values of CRP in pleural punctate had patients with CPPE $(\mathrm{p}<0.001)$, with average value of $150.8 \pm 65.9 \mathrm{mg} / \mathrm{l}$, unlike UCPPE with an average value of $58.1 \pm 42.3 \mathrm{mg} / \mathrm{l}$. The determination of CRP in the pleural fluid in some studies proved to be a good marker for discrimination of UCPPE from CPPE, as in the study of Porcel and collaborators. [31]

Table 6 presentsd the length of hospitalization in patients with UCPPE and CPP . With an average length of 21 days, in participants with CPPE, it significantly differs from the length of the hospitalization in participants with UCPPE, with an average length of hospital treatment of 15 days. This leads to additional costs in the treatment of patients and the use of additional healing techniques with increased morbidity and mortality in patients. $[8,12,19,21,30]$

According to Light's, the classification of parapneumonic effusions with treatment scheme [15] in 8 patients were drained at the Thoraco-cardiovascular Surgery Clinic. In 10 patients, with feature of pleural fluid in addition to just complicated parapneumonic effusions, therapeutic thoracentesis was performed at the Clinic for Infectious Diseases. Limitation of the study is that we did not have the opportunity to use fibrinolytic therapy and to present the results of that kind of treatment.

\section{CONCLUSION}

Patients with parapneumonic effusions have symptoms of acute respiratory infection and frequent accompanying diseases. High temperature that persists in patients with pneumonia, and elevated WBC and CRP suggests that the inflammatory process takes adverse course and is complicating. The characteristics of lung radiography, ultrasonography and analysis of pleural fluid further determine the diagnostic and therapeutic treatment. In today's era of broad-spectrum antibiotics and modern imaging techniques, parapneumonic effusions still present a problem with a multitude of unresolved dilemmas.

\section{Conflict of interest}

We have no conflict of interest to declare. 


\section{REFERENCES}

1. Light RW Parapneumonic effusions and empiema Proc Am Thorac Soc. 2006; 3(1): 75-80.

2. Hasley PB, Albaum MN, Li Y-H, et all. Do pulmonary radiographic findings at presentation predict mortality in patients with community acquired pneumonia? Arch Intern Med 1996; 156: 2206-2212.

3. Girdhar A., Shujaat A, Bajwa A. Management of infectious processes of the pleural space: a review, Pulmonary Medicine 2012; 2012(2012), Article ID 816502, p. 10.

4. Light RW. Pleural diseases, 4th ed Baltimore:Lippincott, Williams and Wilkins; 2001; Virology 2001; 289: 6-14.

5. Chapman SJ, Davies RJO The management of pleural space infection Respitology 2004; 9: 4-11.

6. Mc Cauley L, Dean N. Pneumonia and empiema: causal, causal or unknown J thorac Dis 2015; 7(6): 992-998.

7. Finich S., Chalmers J.D. Parapneumonic effusions: epidemiology and predictors of pleural infection Curr Respir Care Rep 2014; 3: 52-60.

8. Koegelenberg C.F.N., Diacon A.H, Bolliger C.T. Parapneumonic pleural effusion and empyema Respiration 2008; 75: 241-250.

9. Smith JA, Mulleroworth MH, Westlake GW, et al. Empyema thoracis: 14- year expirience in a teaching center. Ann Thorac Surg 1991; 51: 39-42.

10. Medford AR, Maskell N. Pleural effusion. Postgrad Med J 2005; 81: 702e10.

11. Suarez PR, Gilart JF, PerezJMH et al. Treatment of complicated parapneumonical pleural effusion and pleural parapneumonic empiema Med Sci Monit, 2012; 18(7): CR 443-449.

12. Djuric M, Djuric D, Culibrk T, Povazan DJ Parapneumonic effusions: Feautres, diagnostics and treatment options. Srp Arh Celok Lek 2014; 142(11-12): 680-687.

13. Pocrel JM, Light RW Diagnostic approach to pleural effusion in adults Am Fam Physician. 2006 Apr 1; 73(7): 1211-20.

14. Davis HE, Davies RJO, Davies CWH. Management of pleural infection in adults: British Trocracis Society pleural disease guideline 2010 Thorax. 2010; 65(Suppl 2): 41-53.

15. Light RW, Rodriguez RM. Management of parapneumonic effusions Clin Chest Med. 1998 Jun; 19(2): 373-82.

16. Daniil Z.D, Zntzaras E, KIropulus T. et al. Discrimination of exudative pleural effusion based on multiple biological parametars Eur Respir J 2007; 36: 957-964.
17. Ozol D, Oktem S, Erdinc E. Complicated parapneumonic effusion and empyema thoracis: microbiologic and therapeutic aspects. Respir Med.2006; 100: 286-91.

18. Tsang KY, Leung WS, Chan VL, Lin AW, Chu CM. Complicated parapneumonic effusion and empyema thoracis: microbiology and predictors of adverse outcome. Hong Kong Med. 2010; 16(4): 357-61.

19. Chalmers JD, Singanayagam A, Murray MP, et all. Risk factors for complicated parapneumonic effusion and empyema on presentation to hospital with community-acquired pneumonia. Thorax. $2009 \mathrm{Jul}$; 64(7): 592-7.

20. Castro DJ, Diaz G, Perez- Rodrigez E, Light RW. Prognostic features of residual thickening in parapneumonic pleural effusions Eur Respir J 2003; 21: 952-955.

21. Falguera M, Carratalà J, Bielsa S, et all. Predictive factors, microbiology and outcome of patients with parapneumonic effusion. Eur Respir J. 2011 Nov; 38(5): 1173-9.

22. MCGrath EE Anderson PB. Diagnosis of pleural effusion: A systematic approach American Journal of Critical Care 2011; 20: 119-128.

23. Light RW. Management of parapneumonic effusions Egyp Jour of Bronch 2008; 2: 208-212.

24. Shirakabe A, Hata N, Yokoyama Sh. Cytokine levels in pleural effusions of patients under intensive care. Journal of Nippon Medical School 2008; 75(5): 262-26.

25. Brims FJH, Lansley SM, Vaterer GW, Lee YCG. Empyema thoracis: new insights into an old disease. Eur Respir Rev 2010; 19: 117, 220-228.

26. Yang P-C, Luh K-T, Chang D-B et al. Value of sonography in determining the nature of pleural effusion: Analysis of 320 cases AJR Am J Roentgenol. 1992 Jul; 159(1): 29-33.

27. Tsai T-H, Yang P-C Ultrasound in the diagnosis and management of pleural disease Curr Opin Pulm Med. 2003; 9(4).

28. Chin NK Lim TK. Treatment of complicated parapneumonic effusion and pleural empyema: A four- year prospective study. Singapore Med J 1996; 37: 631-635.

29. Vaziri M, Abed O. Managenet of thoracic empyema: Review of 112 cases. Acta Medica Iranica, 2012; 50(3): 203-207.

30. Garrido VV, Sancho JF, Blasco H et al. Diagnosis and treatment of leural effsion. Arch Bronconeumol. 2006; 42(7): 349-72.

31. Porcel JM, Galindo C, Esquerda A et al. Pleural fluid interleukin- 8 and $C$ reactive protein for discrimiating complicated non- purulent from uncomplicatd parapneumonic effusions. Respirology. 2008; 13: 58-62. 


\section{Резиме}

\section{КАРАКТЕРИСТИКИ НА ПАРАПНЕВМОНИЧНИ ИЗЛИВИ}

\section{Сања Петрушевска-Маринковиќ, Ирена Кондова Топузовска, Милена Стевановиќ, Анкица Анастасовска}

Универзитетска клиника за инфективни болести, Медицински факултет, Скопје, Република Македонија

Вовед: Парапневмоничните изливи како компликација на вонболничката пневмонија, вообичаено имаат добар тек, но понекогаш прогресираат во комплицирани парапневмонични изливи и емпием, што претставува сигнификантен клинички проблем.

Целта на студијата е да се прикажат клиничките и радиографските карктеристики, како и нашите дијагностички и терапевтски опции кај пациенти со парапневмоничен излив.

Материјал и методи: Анализата вклучува 94 пациенти со парапневмонични изливи, хоспитализирани на Универзитетската клиника за инфективни болести во Скопје во текот на четиригодишен период. Од 755 пациенти со вонболничка пневмонија, 175 (23,18\%) имале парапневмоничен излив. Торакоцентеза е реализирана кај 94 (53,71\%), 50 пациенти имале некомплициран, 44 пациенти комплициран парапневмоничен излив

Резултати: Најголем дел од пациентите (59,57\%) беа од машки пол, со средна возраст $53,82 \pm 17,5$ години. Најчести нотирани симптоми беа: покачена температура (91; 96,81\%), кашлица $(80 ; 5,11 \%)$, плеврална болка $(68 ; 72,34 \%)$, диспнеа $(65 ; 69,15 \%)$. Алкохолизмот е најчестиот коморбидитет регистриран кај $12(12,77 \%)$ пациенти. Макроскопски, изливите беа жолти и бистри во поголем дел од случаите $(36 ; 38,29 \%)$. Локализација на плевралните изливи начесто беше во левиот френикокостален синус $(53 ; 56,38 \%)$, ултрасонографски со несептиран комплекс. Меѓу двете групи изливи постоеше сигнификантна разлика на вредностите на седиментацијата, леукоцитите и Ц-реактивниот протеин (ЦРП) во серум, како и ЦРП во плевралната течност. Статистичка разлика постоеше и во поглед на деновите на хоспитализација, со подолг престој кај пациентите со комплициран парапневмоничен излив $(\mathrm{p}<0,0001)$.

Заклучок: Пациентите со парапневмоничен излив имаат симптоми на акутна респираторна инфекција и чести придружни болести. Понатамошните дијагностички и терапевтски мерки зависат од карактеристиките на плевралниот излив и промените на белиот дроб со техниките за „имиџинг“.

Клучни зборови: парпневмонични изливи, емпием, карактеристики 